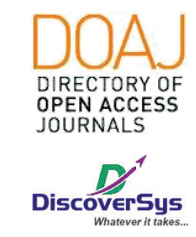

Published by DiscoverSys

\section{Profil penderita katarak traumatika di Rumah Sakit Umum Pusat Sanglah Kota Denpasar, Bali-Indonesia}

\author{
Maria Septiana Parmonang Aroean, ${ }^{*{ }^{*}}$ I Wayan Eka Sutyawan, ${ }^{2}$ \\ Putu Budhiastra, ${ }^{2}$ I Wayan Gede Jayanegara²
}

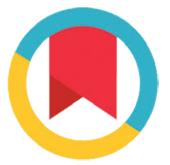

CrossMark

\title{
ABSTRACT
}

Background: Traumatic cataract is a cataract that occurs as a result of injury to the eye which can be a sharp or blunt trauma that is seen after a few days or several years. This traumatic cataract can occur acute, subacute, or residual symptoms of eye trauma, often due to an injury caused by a foreign object that hits the lens or blunt trauma to the eyeball. The purpose of this study was to determine the profile of traumatic cataract sufferers which included the characteristics of age, sex, and occupation at the Sanglah Central Hospital in Denpasar, Bali. Method: This study was descriptive with a cross-sectional study design. This research is retrospective and uses secondary data obtained from medical records.
Result: Results of the study with cross sectional descriptive test showed that $58.3 \%$ of cases occurred in the male sex and $41.7 \%$ in women. The age ranges from 5 years to 69 years with an average sample age of $38.25+2.6$ years. The occupations that dominated were students and farmers with a percentage of $25 \%$ each, followed by housewives with a percentage of $16.7 \%$.

Conclusion: In this study traumatic cataracts were found to be more common in male rice, with an average age of 38 years and occupations as students and farmers. Based on clinical characteristics, the eyes most affected by traumatic cataracts are the left eye and the most common cause is blunt trauma.

Keywords: traumatic cataract, profile, blunt trauma, sharp trauma, characteristics.

Cite This Article: Aroean, M.S.P., Sutyawan, I.W.E., Budhiastra, P., Jayanegara, I.W.G. 2020. Profil penderita katarak traumatika di Rumah Sakit Umum Pusat Sanglah Kota Denpasar, Bali-Indonesia. Intisari Sains Medis 11(2): 750-754. D0I: 10.15562/ism.v11i2.683

\section{ABSTRAK}

Latar Belakang: Katarak traumatika merupakan katarak yang terjadi sebagai akibat cedera pada mata yang dapat merupakan trauma tajam ataupun tumpul yang terlihat sesudah beberapa hari ataupun beberapa tahun. Katarak traumatika ini dapat terjadi akut, subakut, atau pun gejala sisa dari trauma mata, sering terjadi karena adanya cedera yang disebabkan oleh benda asing yang mengenai lensa atau trauma tumpul pada bola mata. Tujuan penelitian ini adalah untuk mengetahui profil penderita katarak traumatika yang meliputi karakteristik usia, jenis kelamin, dan pekerjaan di Rumah Sakit Umum Pusat Sanglah Kota Denpasar, Bali.

Metode: Penelitian ini adalah deskriptif dengan rancangan penelitian potong lintang (cross-sectional). Penelitian ini bersifat retrospektif dan menggunakan data sekunder yang diperoleh dari rekam medis.
Hasil: Hasil penelitian dengan uji deskriptif cross sectional menunjukkan bahwa 58,3\% kasus terjadi pada jenis kelamin lakilaki dan 41,7\% pada perempuan. Usia berkisar dari 5 tahun hingga 69 tahun dengan usia sampel rata-rata 38,25+2,6 tahun. Pekerjaan yang mendominasi adalah siswa dan petani dengan persentase masing-masing $25 \%$, diikuti oleh ibu rumah tangga dengan persentase $16,7 \%$.

Simpulan: Pada studi ini ditemukan katarak traumatika lebih sering terjadi padi laki-laki, dengan rata-rata usia 38 tahun dan pekerjaan sebagai pelajar dan petani. Berdasarkan karakteristik klinis, mata yang paling banyak terkena katarak traumatika adalah mata kiri dan penyebab tersering adalah trauma tumpul.
${ }^{1}$ Fakultas Kedokteran, Universitas Udayana, Bali-Indonesia 2Departemen IImu Kesehatan Mata, Fakultas Kedokteran Universitas Udayana-RSUP Sanglah Denpasar, Bali-Indonesia

\section{*Correspondence to:} Maria Septiana Parmonang Aroean, Fakultas Kedokteran, Universitas Udayana, Bali-Indonesia mariaseptianaa@gmail.com

Diterima: 02-01-2020

Disetujui: 01-07-2020

Diterbitkan: 01-08-2020
Kata kunci: katarak traumatika, profil, trauma tumpul, trauma tajam, karakteristik.

Cite Pasal Ini: Aroean, M.S.P., Sutyawan, I.W.E., Budhiastra, P., Jayanegara, I.W.G. 2020. Profil penderita katarak traumatika di Rumah Sakit Umum Pusat Sanglah Kota Denpasar, Bali-Indonesia. Intisari Sains Medis 11(2): 750-754. D0I: 10.15562/ism.v11i2.683

\section{PENDAHULUAN}

Lensa mata merupakan bagian jernih dari mata yang berfungsi untuk menangkap cahaya dan gambar. Pada keadaan normal, cahaya atau gambar yang masuk akan dterima olen lensa mata, kemudian akan diteruskan ke retina, selanjutnya rangsangan cahaya atau gambar tadi akan diubah menjadi sinyal atau impuls yang akan diteruskan ke otak melalui syaraf penglihatan dan akhirnya akan diterjemahkan sehingga dapat dipahami. ${ }^{1,2}$

Gangguan lensa dapat berupa kekeruhan, dislokasi, dan anomali. Dalam keadaan normal 
transparansi lensa terjadi karena adanya keseimbangan antara protein. Apabila terjadi peningkatan jumlah protein, protein dalam lensa melebihi jumlah protein dalam bagian yang lain sehingga membentuk suatu kapsul yang dikenal dengan nama katarak. ${ }^{2}$

Katarak berarti sebuah opasitas lensa dan istilah katarak berasal dari bahasa yunani "katarraktes" (air terjun) karena pada awalnya terdapat anggapan bahwa katarak adalah cairan beku yang berasal dari cairan otak yang mengalir di depan lensa. Katarak adalah penyebab kebutaan yang paling sering dihadapi oleh ahli bedah mata. Hal ini tidak berarti bahwa setiap orang yang menderita katarak kemungkinan besar akan menjadi buta. Untungnya, hasil pengobatan dengan operasi memberikan hasil yang baik, peningkatan kemampuan penglihatan yang didapatkan cukup memuaskan pada lebih dari $90 \%$ kasus. Proses penuaan adalah penyebab katarak yang paling banyak, tetapi masih banyak faktor lain yang dapat terlibat, yang mencakup trauma, keracunan, penyakit sistemik (seperti diabetes), merokok dan herediter. ${ }^{2,3}$

Katarak traumatika disebakan oleh trauma okulasi perforasi atau non perforasi. Cahaya infra merah (glass-bloer's cataract), sengatan listrik, dan radiasi ionisasi adalah penyebab lain katarak traumatika yang jarang terjadi. Katarak yang disebabkan oleh trauma tumpul biasanya membentuk opasitas aksial posterior yang berbentuk stellae atau rosette yang mungkin stabil atau progresif, sedangkan trauma okuli perforasi dengan gangguan kapsul lensa dapat menyebabkan perubahan kortikal yang dapat tetap bersifat lokal jika lukanya kecil atau dapat berkembang dengan cepat menjadi total cortical opacification. ${ }^{2,4}$

Di Amerika serikat diperkirakan terjadi 2,5 juta trauma mata setiap tahun. Kurang lebih 4-5\% dari

Tabel 1 Karakteristik Umum Sampel Penelitian

\begin{tabular}{lc}
\hline Karakteristik & Frekuensi (n=12) \\
\hline Jenis Kelamin n,(\%) & $7(58,3)$ \\
Lelaki & $5(41,7)$ \\
Perempuan & $38,25+2,6$ \\
Usia (tahun; mean+SD) & \\
Pekerjaan, n(\%) & $2(16,7)$ \\
IRT & $1(8,3)$ \\
Pegawai Swasta & $3(25,0)$ \\
Pelajar & $1(8,3)$ \\
Pensiunan & $3(25,0)$ \\
Petani & $1(8,3)$ \\
Wiraswasta & $1(8,3)$ \\
Tidak Bekerja & \\
\hline
\end{tabular}

pasien-pasien mata yang membutuhkan perawatan komprehensif merupakan keadaan sekunder akibat trauma mata. Trauma merupakan penyebab tertinggi buta monokular pada orang kelompok usia di bawah 45 tahun. Setiap tahunnya diperkirakan 50.000 orang tidak dapat membaca koran sebagai akibat trauma mata. ${ }^{4}$ Dilihat dari jenis perbandingan kejadian katarak traumatika laki-laki dan perempuan adalah 4:1. National Eye Trauma System Study melaporkan rata-rata usia penderita katarak traumatic adalah 28 tahun dari 648 kasus yang berhubungan dengan trauma mata.

Pasien yang mengalami gangguan pada lensa mengalami kekaburan penglihatan tanpa adanya nyeri. Pemeriksaan yang dilakukan adalah pemeriksaan ketajaman penglihatan dan dengan melihat lensa melalui slitlamp, oftalmoskop, senter tangan, atau kaca pembesar, sebaiknya dengan pupil yang terdilatasi. $^{4}$

Tujuan dilakukannya penelitian ini adalah untuk mengetahui profil penderita katarak traumatika yang meliputi karakteristik usia, jenis kelamin, maupun pekerjaan, di RSUP Sanglah Denpasar, Bali.

\section{METODE}

Metode yang akan digunakan dalam penelitian ini adalah deskriptif dengan rancangan penelitian potong lintang (cross-sectional). Penelitian ini bersifat retrospektif dan menggunakan data sekunder yang diperoleh dari rekam medis. Penelitian ini dilakukan di RSUP Sanhlah pada periode Februari 2018 hingga Juli 2018. Seluruh pasien katarak traumatika kemudian dilakukan penelusuran terhadap karakteristik (jenis kelamin, usia, pekerjaan, lateralitas, tajam pengelihatan, dan penyebab trauma). Data akan dilakukan analisis secara deskriptif dan ditampilkan dalam bentuk tabel menggunakan bantuan perangkat lunak SPSS versi 17.0 untuk Windows.

\section{HASIL PENELITIAN}

Dari pengumpulan data yang dilakukan pada bulan Juli 2019 hingga Oktober 2019, didapatkan total 12 kasus katarak tarumatika yang terdaftar di RSUP Sanglah pada periode Februari hingga Juli 2018. Ditemukan bahwa 58,3\% dari kasus terjadi pada jenis kelamin laki-laki dan $41,7 \%$ nya pada perempuan. Usia memiliki rentangan dari 5 tahun hingga 69 tahun, dengan rerata usia sampel adalah $38,25+$ 2,6 tahun. Pekerjaan yang mendominasi adalah pelajar dan petani dengan persentase masingmasing 25\%, diikuti dengan ibu rumah tangga dengan persentase $16,7 \%$. Data selengkapnya dapat dilihat pada Tabel 1. 
Tabel 2 Karakteristik Katarak Traumatika

\begin{tabular}{lc}
\hline Karakteristik & Frekuensi (n=12) \\
\hline Bilateralitas n,(\%) & \\
Sinistra & $8(66,7)$ \\
Dextra & $3(25,0)$ \\
Dextra ad Sinistra & $1(8,3)$ \\
Penyebab n,(\%) & \\
Trauma Tumpul & $11(91,7)$ \\
Trauma Tajam & $1(8,3)$ \\
Visus n,(\%) & \\
1/300 & $5(41,7)$ \\
1/60 & $1(8,3)$ \\
$6 / 15$ & $2(16,7)$ \\
$6 / 45$ & $1(8,3)$ \\
LP & $1(8,3)$ \\
NLP & $2(16,7)$ \\
\hline
\end{tabular}

Tabel 3 Karakteristik Katarak Traumatika Berdasarkan Jenis Kelamin

\begin{tabular}{lcc}
\hline & \multicolumn{2}{c}{ Jenis Kelamin } \\
\cline { 2 - 3 } Karakteristik & Lelaki (n=7) & Perempuan (n=5) \\
\hline Bilateralitas n,(\%) & $4(57,1)$ & $4(80,0)$ \\
Sinistra & $3(42,9)$ & $0(0,0)$ \\
Dextra & $0(0,0)$ & $1(20,0)$ \\
Dextra ad Sinistra & & \\
Penyebab n,(\%) & $6(85,7)$ & $5(100)$ \\
Trauma Tumpul & $1(14,3)$ & $0(0,0)$ \\
Trauma Tajam & & $2(40,0)$ \\
Visus n,(\%) & $3(42,9)$ & $1(20,0)$ \\
1/300 & $0(0,0)$ & $1(20,0)$ \\
$1 / 60$ & $1(14,3)$ & $0(0,0)$ \\
$6 / 15$ & $1(14,3)$ & $0(0,0)$ \\
$6 / 45$ & $1(14,3)$ & $1(20,0)$ \\
LP & $1(14,3)$ & 1 \\
NLP & & \\
\hline
\end{tabular}

Dilihat dari karakteristik kasus katarak traumatika, ditemukan bahwa katarak traumatika lebih sering terjadi pada okuli sinistra dengan persentase $66,7 \%$. Ditemukan 1 kasus yang melibatkan kedua mata. Penyebab tersering katarak traumatika adalah trauma tumpul dengan persentase kejadian $91,7 \%$. Berdasarkan pencatatan rekam medis, tidak semua menyertakan benda penyebab trauma akan tetapi diketahui satu kasus trauma tumpul disebabkan oleh kayu dan dua kasus disebabkan oleh batu. Sedangkan trauma tajam hanya terjadi pada 1 kasus dengan benda penyebab adalah paku.
Berdasarkan penilaian visus, ditemukan 2 pasien yang tidak memiliki persepsi cahaya pada mata yang mengalami katarak traumatika dan 1 pasien yang hanya dapat mempresepsi cahaya. Kebanyakan pasien yaitu $41,7 \%$ memiliki visus $1 / 300$. Data selengkapnya dapat dilihat pada Tabel 2.

Penulis membandingkan karakteristik katarak traumatika berdasarkan jenis kelamin pasien dan menemukan bahwa pada pasien lelaki ditemukan 42,9\% mengalami katarak traumatika pada okuli dekstra sedangkan $80 \%$ perempuan mengalami pada sisi kiri. Katarak traumatika yang terjadi pada kedua mata hanya terjadi pada perempuan.

Berdasarkan penyebab trauma, ditemukan bahwa tidak ada pasien perempuan yang mengalami trauma tajam sebagai penyebab katarak traumatika sedangkan 1 orang lelaki mengalami trauma tajam.

Perhitungan visus pada perempuan dan lakilaki menunjukkan hasil yang hampir serupa. Data selengkapnya dapat dilihat pada Tabel 3.

\section{PEMBAHASAN}

\section{Karakteristik Katarak Taumatika}

Dalam studi ini ditemukan hampir seluruh kasus katarak traumatika terjadi pada okuli sinistra. Belum terdapat banyak studi yang membahas mengenai sisi mata yang terkena pada katarak traumatika, akan tetapi salah satu studi yang dilakukan oleh Smith dkk menunjukkan hasil yang sedikit berbeda dengan temuan studi ini, dimana mereka menunjukkan bahwa 51\% dari kasus katarak tarumatis terjadi pada mata kanan sedangkan 49\% sisanya pada mata kiri. Akan tetapi penulis tidak menjelaskan pengaruh kecenderungan dari sisi mata yang terkena pada katarak traumatika. ${ }^{5}$

Penyebab tersering dari katarak traumatika pada studi ini adalah trauma tumpul. Hal ini serupa dengan hasil studi yang diungkapkan oleh Netralaya pada tahun 2015, dimana ia menemukan bahwa hanya $0,7 \%$ kasus katarak traumatika yang disebabkan oleh benda tajam berupa kaca dan 1,2\% kasus lainnya disebabkan oleh benda tajam lainnya. Benda penyebab sisanya merupakan benda tumpul dengan dominasi kayu (55,9\%) disusul oleh batu (13,5\%). ${ }^{6}$ Pada studi ini memang tidak dilengkapi benda penyebab trauma dikarenakan hanya sebagian kecil studi yang menyertakan benda penyebab trauma pada pencatatan rekam medis, akan tetapi ditemukan bahwa terdapat subjek yang mengalami trauma akibat lemparan batu, kayu dan paku. Hasil yang berbeda ditunjukkan oleh studi yang dilakukan oleh Du dkk yang meneliti kejadian katarak traumatika pada populasi pediatric. Mereka menemukan bahwa justru 
trauma tajamlah yang menjadi penyebab utama katarak traumatika $(40,2 \%)$ dimana benda tersebut $67,4 \%$ nya berupa gunting, $17,8 \%$ berupa pisau dan 10,08\% nya berupa jarum. Mereka mengatakan bahwa kebanyakan pasien dengan trauma tumpul tidak mengingat penyebab traumanya karena terkena secara tiba-tiba saat melakukan aktivitas di luar ruangan. ${ }^{7}$ Memon dkk juga menunjukkan hasil serupa pada studi yang dilakukan di populasi umum dimana benda penyebab tersering dari katarak traumatika adalah benda tajam dengan persentase 68,3\%, mereka menjelaskan hasil ini disebabkan karena kebanyakan sampel mereka adalah anak-anak hingga dewasa muda dan hanya $24,4 \%$ sampel mereka adalah dewasa. ${ }^{8}$

Visus yang ditemukan kebanyakan adalah 1/300. Hal ini sesuai dengan hasil temuan Netralaya dimana ia menemukan bahwa sebagian besar subjek yang menderita katarak traumatika memiliki visus di bawah $1 / 60$ pada mata yang terkena dengan persentase $84,7 \%$. Dari 675 sampel, hanya ada 1 orang yang masih memiliki visus 6/6 setelah mengalami katarak traumatika. ${ }^{6}$ Studi yang dilakukan oleh Memon dkk menunjukkan bahwa $76.5 \%$ pasien hanya memiliki persepsi cahaya pada mata yang terkena dan visus tertinggi adalah 6/24 dan hanya terjadi pada 1 kasus. ${ }^{8}$ Hasil ini masih konsisten pada studi yang dilakukan 3 tahun setelahnya dimana ditemukan 90,8\% penderita katarak traumatika memiliki visus lebih buruk dari 1/100 pada mata yang terkena. ${ }^{7}$ Dalam studi ini, terdapat 2 kasus dengan kebutaan total di mata yang terkena dimana tidak terdapat persepsi cahaya. Studi yang dilakukan di USA menemukan bahwa dari 181 kasus katarak traumatika, ditemukan $44(24,30 \%)$ yang memiliki visus tanpa persepsi cahaya. Dikatakan bahwa jenis trauma mempengaruhi visus yang dimiliki pasien, dimana pada mata dengan trauma tajam, rerata visus adalah 20/35 dengan persentase rendah pada visus persepsi cahaya maupun tanpa persepsi cahaya. Sedangkan pada trauma tumpul, persentase visus tanpa persepsi cahaya lebih tinggi dimana 39,3\% kasus disebabkan karena lepasnya retina pada trauma tumpul dan 22,6\% akibat kerusakan kornea sentral. ${ }^{5}$ Studi yang dilakukan di RS Tersier di India menemukan bahwa visus pada katarak tarumatis $50 \%$ terdiri atas persepsi cahaya/ gerakan tangan dan 37,5\% memiliki visus di bawah 3/60 dengan buruknya visus berasosiasi dengan kerusakan kornea pada $77 \%$ pasien. Akan tetapi, dalam studi tersebut diterangkan bahwa visus pada kasus katarak traumatis sebesar 70\% nya akan mengalami perbaikan menjadi lebih dari $6 / 18$ sedangkan pada $27,5 \%$ kasus menjadi $6 / 18$ $3 / 60$ setelah dilakukan operasi penggantian lensa. ${ }^{9}$

\section{Pengaruh Jenis Kelamin terhadap Karakteristik Katarak Tarumatika}

Meskipun studi ini tidak menghitung signifikansi perbedaan karakteristik klinis pada katarak traumatika, ditemukan beberapa tampilan klinis yang berbeda antara lelaki dan perempuan seperti yang telah dijabarkan pada hasil penelitian diatas. Studi yang membedakan karakteristik katarak traumatika berdasarkan jenis kelamin masih belum tersedia, akan tetapi terdapat 2 studi yang mempertimbangkan jenis kelamin sebagai faktor prediktor luaran dari kasus katarak traumatika. Mereka menemukan bahwa wanita 4,38 kali lebih cenderung untuk memiliki luaran yang kurang optimal terutama pada visus setelah intervensi (visus $<6 / 18$ ) dibandingkan dengan perempuan (95\% CI=1,96-9,79; $\mathrm{p}<0,001)$. Mereka juga menemukan bahwa wanita cenderung memiliki pupil yang irregular $(26,5 \%$ vs $14,8 \%$; $<<0,05)$ dan astigmatisme yang lebih parah $(27,5 \%$ vs $18,2 \%$; $p<0,05)$ hal inilah yang menyebabkan cenderung lebih buruknya luaran dari tatalaksana katrarak traumatika pada perempuan. ${ }^{10}$ Studi lain dari Gilbert dkk menunjukkan bahwa hasil yang buruk pada kasus katarak traumatika pada perempuan dikaitkan dengan akses pembedahan perempuan yang lebih sulit dibandingkan dengan lelaki terutama di wilayah berpendapatan rendah. ${ }^{11}$

\section{Keterbatasan Studi}

Studi ini terbatas dalam hal desain penelitian yang tidak membutuhkan follow up dalam waktu tertentu. Selain itu, studi ini bersifat deskriptif sehingga tidak dapat dilihat adanya korelasi dan hubungan sebab akibat di antara variabel. Keterbatasan waktu penelitian dan kelengkapan pencatatan rekam medis menyebabkan jumlah sampel yang diperoleh dalam studi ini sedikit.

\section{SIMPULAN}

Pada studi ini ditemukan katarak traumatika lebih sering terjadi pada lelaki, dengan rerata usia 38 tahun dan pekerjaan sebagai pelajar dan petani. Lelaki cenderung lebih mudah mengalami katarak traumatika diduga akibat adanya perbedaan partisipasi lelaki pada aktivitas di luar ruangan yang meningkatkan kemungkinan terjadinya trauma. Berdasarkan karakteristik klinis, mata yang paling banyak terkena katarak traumatika adalah mata kiri dan penyebab tersering adalah trauma tumpul.

\section{KONFLIK KEPENTINGAN}

Penulis menyatakan tidak terdapat konflik kepentingan terkait publikasi dari penelitian ini. 


\section{PENDANAAN}

Penelitian ini tidak mendapat bantuan dana dari pemerintah ataupun sector swasta lainnya.

\section{DAFTAR PUSTAKA}

1. Ilyas S. Ilmu Penyakit Mata. $3^{\text {rd }}$ ed. Jakarta: Balai Penerbit Fakultas Kedokteran Universitas Indonesia; 2015.

2. Vaughan D. Oftalmologi Umum. Edisi 17. Penerbit Buku Kedokteran EGC, Jakarta; 2010.

3. Olver J, Cassidy L. Ophthalmology at A Glance. Massachusetts: Blackwell Science; 2015.

4. Shah M, Shah S, Gupta L, Jain A, Mehta R. Predictors of Visual Outcome in Traumatic Cataract. World J Opthamol. 2014;12(4):152-159.

5. Smith M, Colyet M, Weichel W, Stutzman R. Traumatic cataracts secondary to combat ocular trauma. J Cataract Refract Surg. 2015;41:1693-1698.

6. Netralaya D. Traumatic Cataract- A Review. Resc Gate. 2015;15(1):31-67.

7. Du Y, He W, Sun X, Lu Y, Zhu X. Traumatic Cataract in Children in Eastern China: Shanghai Pediatric Cataract Study. Scientific reports. 2018;8:2588-2597.
8. Memon M, Nasrani A, Nizamani N. Visual Outcome of Unilatera; Traumatic Cataract. Journal of College Physicians and Surgeons Pakistan. 2012;22(8):497-500.

9. Jagannath C, Penchalaiah T, Swetha M, Prabhu GR. Visual outcome of traumatic cataract in a tertiary carehospital, Tirupati. IAIM. 2015;2(9):111-115.

10. Ahmad K, Zwi AB, Tarantola DJM, Soomro AQ, Baig R, Azam SI. Gendered Disparities in Quality of Cataract Surgery in a Marginalised Population in Pakistan: The Karachi Marine Fishing Communities Eye and General Health Survey. PLoS ONE. 2015;10(7):e0131774.

11. Gilbert C, Labpvier N, Chomette E. Gender Inequalities in Surgery for Bilateral Cataract among Children in LowIncome Countries. Ophthalmology. 2016;123:1245-1251.

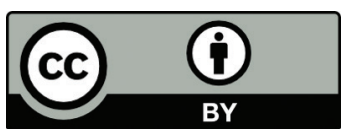

This work is licensed under a Creative Commons Attribution 